\title{
Islamic law review on use of Go-Pay in payment of zakat
}

\author{
Laila Afni Rambe \\ Universitas Islam Negeri (UIN) Sunan Kalijaga Yogyakarta \\ Jl. Laksda Adisucipto, Papringan, Catur tunggal, Kec. Depok, \\ Kabupaten Sleman, Daerah Istimewa Yogyakarta 55281 \\ Email: lailaafnirambe20@gmail.com
}

\begin{abstract}
Abstrak
Perkembangan teknologi ternyata memberikan pengaruh besar dalam perubahan transaksi ekonomi masyarakat. Sistem yang dulunya digunakan masyarakat merupakan sebuah sistem manual namun perkembangan teknologi membawanya hingga berubah menjadi sistem online yang semua transaksi bisa dilakukan tanpa harus bertatap muka, tanpa dipengaruhi oleh waktu dan tempat. Sehingga masyarakat dimanjakan oleh sistem tersebut. Tidak hanya dalam lingkup transaksi ekonomi seputar perdagangan namun sistem online ini juga telah digunakan dalam transaksi pembayaran zakat yang menggunakan uang elektronik. Adapun tujuan dari pada penelitian ini adalah untuk melihat bagaimana hukum penggunaan uang elektronik ketika digunakan untuk membayar zakat. Untuk mencapai tujuan dari penelitian ini penulis menggunakan metode penelitian pustaka (library research) yaitu dengan memeriksa dokumen baik yang diterbitkan secara resmi ataupun yang terdapat diseluruh bahan cetakan, maupun berbentuk elektronik yang berkaitan dengan topik yang dibahas. Dari hasil analisis yang penulis lakukan terhadap data tersebut dapat disimpulkan bahwa uang elektronik GoPay tidak boleh digunakan karena tidak sesuai dengan ketentuan DSN-MUI. Ketika uang elektronik atau Go-Pay tidak boleh digunakan maka Go-Pay juga tidak boleh digunakan untuk membayar zakat.
\end{abstract}

Kata Kunci: Zakat, hukum Islam, uang elektronik, Go-Pay

\begin{abstract}
Technological developments turned out to have a major influence on changes in community economic transactions. The system that was once used by the community is a manual system but technological developments bring it to change into an online system that all transactions can be done without having to face to face, without being influenced by time and place. So, that the community is spoiled by the system. Not only in the scope of economic transactions around trade, but this online system has also been used in zakat payment transactions that use electronic money. The purpose of this research is to see how the legal use of electronic money when used to pay zakat. To achieve the objectives of this study the authors use the method of library research, namely by examining documents both published officially or contained in all printed materials, or in electronic form relating to the topics discussed. From the results of the analysis conducted by the author on these data it can be concluded that electronic money GoPay may not be used because it is not in accordance with the provisions of DSN-MUI. When electronic money or Go-Pay should not be used, Go-Pay also should not be used to pay zakat.
\end{abstract}

Keywords: Zakat, Islamic law, electronic money, Go-Pay

\section{Introduction}

$\mathbb{Q}$ long with the development of modern technology now a days, there are very many online startup applications that are the result of the nation's hard work. It has even begun to level up to a decacorn company that was previously still in a unicorn level. For example, companies such as Tokopedia, 
Gojek, Bukalapak and so on. Until now all these applications are still a favorite application that is very popular with the public, not only limited to the fulfillment of applications on mobile phones, but also serves as a tool in carrying out daily activities for the wearer. According to the large Indonesian dictionary, the application is the application of a system design to process data that uses certain programming language rules or conditions ${ }^{1}$.

In expediting the operational work of star-up applications, electronic wallet as a payment medium is provided by various companies. Electronic wallet is an electronic service for storing or storing payment instrument data at any time if you want to make non-cash payments, for example Go-Pay.

Go-Pay is one of the mainstay services offered by the company PT. Gojek Indonesia which is a start-up company that is currently in its infancy. Go-Pay service aims to make it easier for Gojek customers to make payments for services that have been received. This Gojek company was founded in 2010 by Nadiem Makarim. Starting from an online transportation service offering. It was only in 2015 Gojek began to explore other business lines. Ranging from food delivery services (Go-Food), cleaning services (Go-Clean), freight services, courier services (Go-Send), lifestyle services such as salons, massages (Go-Message) and many more.

With this online application, it certainly can make it easier for people to do their daily activities, including carrying out economic transactions such as purchases, sales, bill payments, and even paying zakat.

The existence of zakat becomes very strategic and very effective in increasing the economic value of society. Not only spiritual but also economic and social value in the development and economic improvement of the Ummah.

The management of zakat in Indonesia itself is carried out by the national amil zakat body which is often abbreviated as BAZNAS. BAZNAS is the official and only body formed by the Indonesian government based on Presidential Decree No. 8 of 2001 whose duty and function is to collect, distribute and manage zakat, infaq and alms (ZIS) at the national level.

Considering its duties and functions, BAZNAS also cooperates with the gojek company in collecting zakat funds ${ }^{2}$, this is done considering that more adult people use payments with electronic money or non-cash so it is relevant to the times. Gojek company is a media for distributing zakat from the public through the zakat payment program using Go-Pay. Partnering with PT Gojek Indonesia, the amil zakat body (BAZNAS) opens the opportunity for every Muslim to start paying zakat through a digital wallet that is fintech (financial technology). It is known that there are two parties involved in collecting zakat funds through GoPay, namely BAZNAS as amil zakat and PT Gojek Indonesia.

\footnotetext{
${ }^{1}$ Departemen Pendidikan Nasional, Kamus Besar Bahasa Indonesia (Jakarta: Balai Pustaka, 2007), p. 155.

2 Fundraising is an activity carried out to collect funds and other resources from the community that will be used to fund a program and the operational activities of the institution so as to achieve its objectives. See Miftahul Huda, Pengelolaan Wakaf Dalam Perspektif Fundraising (Jakarta: Kementrian Agama RI, 2012), p. 27.
} 
Zakat payment by Go-Pay can be said to be still new in Indonesia because all this time zakat payment is done manually only by paying zakat directly to BAZNAS. As something new in the payment of zakat, of course it is necessary to explore how the legal use of Go-Pay when paid for zakat.

Previous studies on Syariah Electronic Money (Flazz BCA, Go-Pay and Grab Pay Card Studies) show that based on the DSN-MUI fatwa No: 116 / DSNMUI / IX / 2017 concerning Syariah electronic money, BCA, Go-Pay and Grab Flazz Cards Pay is not allowed because the issuer places a float fund in a conventional bank while in the fatwa the float fund must be kept in a Syariah Bank ${ }^{3}$. On the other hand, the study of Efficiency Analysis on the Implementation of Fintech in E-Zakat as a Zakat Fund Collection Strategy by Lazizmu and Nurul Hayat also shows that the E-Zakat system in amil zakat institutions, both Lazismu and Nurul Hayat, provides a very supportive role in collecting zakat funds, due to the ease of being felt by the community so that it becomes a driver of public awareness to pay zakat.

Legal analysis using Go-Pay to pay zakat is important to do by looking at how the legal provisions of electronic money that can be used for further analysis, the zakat payment law can be explained through Go-Pay so that the zakat payment agreement is also clear.

\section{Research method}

\section{Types of research}

This type of research is social legal research (social legal research) in which the data is obtained through: Library research, namely by examining documents both officially published or contained in all printed materials, as well as in electronic form relating to the topics discussed. ${ }^{4}$

\section{Data, instruments, data collection techniques}

There are two kinds of data to be obtained namely: primary data and secondary data, the data referred to by the author are books, legal journals, research results, legal papers, and books that are relevant to the object under study and the problem to be examined. ${ }^{5}$

Because this type of research is library research that is inseparable from the researchers' direct observations of the data collected so that this type of research is library research that is inseparable from the direct observation of the researchers of the data collected, so the research instruments are a list of literature, notebooks and so forth. So, the research instrument is a list of literature, notebooks and so forth.

3 Novia Nengsih, “ANALISIS TERHADAP FATWA DEWAN SYARI'AH NASIONAL MAJELIS ULAMA INDONESIA (DSNMUI) TENTANG UANG ELEKTRONIK SYARIAH (Studi Kartu Flazz BCA, Go-Pay, Dan Grab-Pay)," Jurisdictie 10, no. 1 (2019): 56, doi:10.18860/j.v10i1.6594, p. 22.

${ }^{4}$ Sugiono P.D, Metode Penelitian Pendidikan Pendekatan Kuantitatif.Pdf, Metode Penelitian Pendidikan Pendekatan Kuantitatif, Kualitatif Dan RED, 2014, p. 12.

${ }^{5}$ William Chang, Metode Penulisan Esai, Skripsi, Tesis, Dan Disertasi Untuk Mahasiswa (Jakarta: Erlangga, 2014), p. 38. 
To obtain relevant data, the authors use data collection techniques with library research. Literature research, which is collecting data from written literature, includes books on accounts payable and credit, Islamic economics, articles on the internet, documents relating to research topics. ${ }^{6}$

\section{Data analysis technique}

After the author conducted research into the library, the writer identified the problem that the writer found in the field related to the problem in this study, namely the payment of zakat by using Go-Pay. Then the authors formulate in accordance with the formulation of the problem in this study, namely about the review of Islamic law on the use of Go-Pay in zakat payment.

From all data obtained, the data relevant to the research are classified. The technique used to analyze the data in this study is a descriptive qualitative analysis method, which is carried out with a descriptive analysis method that is interpreting data relating to facts and phenomena that occur.

\section{Results and discussion}

\section{Position of Go-Pay in financial institutions}

According to the Decree of the Minister of Finance of the Republic of Indonesia Number 792 of 1990 concerning financial institutions, a financial institution is anybody or institution whose activities are in the financial sector, raising funds and channeling funds to the public, especially to finance company investment. $^{7}$

Financial institutions also have several types, namely:

1. Bank financial institutions.

Bank financial institutions, namely an institution or entity whose principal business is providing credit and services in payment traffic and money supply. ${ }^{8}$ Banks as an institution have the main task of collecting funds directly from customers in the form of deposits and then indirectly in the form of bonds and loans from other institutions. The funds collected are intended for working capital, investment and consumption to business entities and the public who need funds. ${ }^{9}$

2. Non-bank financial instructions.

Non-bank financial institutions are all bodies that carry out activities in the financial sector, raising funds indirectly from the public by issuing securities or bonds and can also be from loans or credit from other institutions. ${ }^{10}$

Go-Pay is an electronic wallet or electronic money that is often called EMoney. According to the Bank for International Settlements (BIS) in its publication

\footnotetext{
${ }^{6}$ Lexy Moleong J, Metodologi Penelitian Kualitatif (Bandung: PT Remaja Rosdakarya, 2016), p. 159.

7 “Surat Keputusan Menteri Keuangan Republik Indonesia Nomor 792 Tahun 1990 Tentang Lembaga Keuangan." (n.d.).

8 "Undang-Undang Nomor 14 Tahun 1967 Tentang Pokok-Pokok Perbankan" (n.d.).

9 Tamrin Abdullah dan Francis Tantri, Bank Dan Lembaga Keuangan, 1st ed. (Jakarta: Rajawali Press, 2012), p. 3.

10 Totok Budisantoso dan Nuritumo, Bank Dan Lembaga Keuangan Lain (Jakarta: Salemba Empat, 2017), p. 5.
} 
in 1996, defining electronic money was a stored value product in which a number of money values were stored in a digital application where the amount of money value could be obtained if the balance was filled in the digital application. ${ }^{11}$

Furthermore, the Consultative Group to Assist the Poor (CGAP) which is a supervisory institution under the World Bank, e-money is interpreted as electronic money stored in a digital application, used as a payment instrument that can be accepted by the general public which can then be converted into cash. ${ }^{12}$

Likewise, in the report on electronic money by the Group of Ten, e-money is interpreted as an electronic means of payment through the internet network which today has begun to be applied by a number of markets in improving business operations ".13

Also known in Indonesia is Bank Indonesia, which has the authority to issue money. Seeing the development of payment instruments in the form of electronic money. Bank Indonesia also provides an opinion regarding the meaning of electronic money that is truly in accordance with the regulations in force in Indonesia, namely contained in Bank Indonesia Regulation Number 11/12 / PBI / 2009 concerning Electronic Money. This is contained in Chapter I which reads: that electronic money (Electronic Money) is a means of payment that meets the following elements:

1. Issued on the basis of the value of money paid in advance by the holder to the issuer.

2. Value of money is stored electronically in a medium such as a server or chip.

3. used as a means of payment to traders who are not the issuers of electronic money; and

4. the value of electronic money deposited by holders and managed by the issuer is not a deposit as referred to in the law governing banking. ${ }^{14}$

Not lagging behind Bank Indonesia, the Indonesian Ulama Council (MUI) ${ }^{15}$ also gave an explanation of the increasingly circulating electronic money. So, it is deemed necessary to further review how the concept of electronic money in

${ }^{11}$ Bank for Internatinal Settlement, Implications for Central Bank of the Development of Electronic Money (BIS, 1996), p. 1.

12 Kate Lauer dan Michael Tarazi, "Supervising Nonbank E-Money Issuers'," 2010, www.cgaap. org/.../CGAP-Brief-Supervising-Nonbank-Emoney-\%3E.

${ }^{13}$ Committee on Payment and Settlement Systems, "Survey of Developments in Electronic Money and Internet and Mobile Payment," 2004.

14 Bank Indonesia, “PERATURAN BANK INDONESIA NOMOR: 11/12/PBI/2009 TENTANG UANG ELEKTRONIK (ELECTRONIC MONEY).

${ }^{15}$ Indonesian Ulema Council (MUI) is an independent religious community organization, in the sense of not being bound and siding with any government or organization. MUI was established in 17 Rajab $1375 \mathrm{H}$ to coincide on July 26, 1975. MUI is a forum for discussion and discussion of Muslim scholars, leaders and scholars in guiding people and developing their lives in an Islamic, democratic, open and active way. In carrying out its role and function, the MUI has also formed a number of commissions and bodies under the auspices of the MUI itself, one of which is the National Sharia Council (DSN). DSN is one of the institutions formed by the MUI to deal with issues related to the activities of Islamic financial institutions by issuing fatwas relating to types of activities, products, Islamic financial services and overseeing all Islamic financial institutions. See, M Cholil Nafis, Teori Hukum Ekonomi Syariah (Jakarta: Universitas Indonesia Press, 2011), p. 5-8. 
accordance with sharia. DSN-MUI provides the concept of electronic money as contained in the fatwa of the National Sharia Council of the Indonesian Ulema Council Number 116 / DSN-MUI / IX / 2017 concerning sharia electronic money. In the aforementioned fatwa provisions that what is meant by electronic money is a means of payment that meets the following elements:

1. Issued on the basis of the nominal amount of money deposited in advance to the issuer.

2. The nominal amount of money deposited electronically in a registered medium.

3. The nominal amount of electronic money managed by the issuer does not constitute deposits as referred to in the law governing banking; and

4. Used as a means of payment to traders who are open is the issuer of electronic money.

From the explanation above it can be seen that electronic money is nonphysical money or non-cash money. Electronic Money Value is the value of money that is stored electronically on a medium that can be moved for the benefit of payment transactions and / or fund transfers. The value of electronic money can be obtained from the process of exchanging cash for electronic money which will be stored in a digital application system. Electronic money can be used to trade economically with traders or sellers. If an economic transaction has been carried out whether it is buying and selling or other muamalah contracts, the value of the electronic money will be reduced according to the number of transactions for the expenditure of the E-Money owner.

Go-Pay itself is issued by PT Dompet Anak Bangsa which aims to make payments at any time on all transactions offered by Gojek. The Go-Pay service on the Gojek application began to be offered in mid-2016 amid intense business competition. Go-Pay registered and monitored by Bank Indonesia has collaborated with several leading banks in Indonesia including: Centra Asia bank, Mandiri bank, BRI bank, BNI bank, Permata bank, BTN bank, BRI Syariah, Danamon, Harvest bank, Sinarmas bank, Bukopin bank, Maybank, and several other banks that have technology support. ${ }^{16}$

The fundamental difference between ATMs, credit cards or debit cards with Go-Pay can be seen in terms of storage. It is very clear the difference between Go-Pay with an ATM card because Go-Pay itself is stored in the digital system of the Gojek application on the user's android mobile phone while the E-money on the ATM is stored on a card. In addition, there are other striking differences that in Go-Pay user balance is not subject to storage service fees that are usually taken by the company or application owner. Whereas in ATMs, each month there will be a retrieval of storage service fees taken directly from the user's ATM card. Besides e-money in Go-Pay can also be cashed by transferring to the user's account through the feature to withdraw the nominal amount of e-money. ${ }^{17}$

16 "Mitra Go-Pay," accessed November 4, 2019, www.gojek.com/gopay/kebijakan-privasi/.

${ }^{17}$ Nengsih, "ANALISIS TERHADAP FATWA DEWAN SYARI'AH NASIONAL MAJELIS ULAMA INDONESIA (DSNMUI) TENTANG UANG ELEKTRONIK SYARIAH (Studi Kartu Flazz BCA, Go-Pay, Dan Grab-Pay)", p. 73. 
The position of Go-Pay in financial institutions includes non-bank financial institutions that are financial technology (fintech). Fintech is a collaboration of financial services with technology. Fintech changed the business model from conventional to moderate, which initially had to pay face to face (face to face) and carry some cash, now it can be done remotely, utilizing the internet network, or can be referred to online. The aim is to provide access to financial products so that transactions become more practical and effective.

The existence of fintech is in line with the changing style of society which has begun to be dominated by the large number of people using fast-paced information technology. Starting from buying and selling transactions, leasing or even other muamalah transactions. This is motivated by the reluctance of some people to cash transactions for certain reasons. Call it for example caused by the inconvenience of shopping at the market or the lack of time to transfer money through an ATM. So thus, the public begins to switch transactions with the online system. It was there that fintech was present as a solution to help people simplify their transactions with a payment system that was more economical, efficient and still effective.

The birth of this fintech has changed the payment system in the midst of society which basically already requires simplifying payments by helping star-up companies in carrying out their operations. In this case fintech is able to replace the role of formal financial institutions such as banks in the payment system. By playing a role in providing markets for businesses, becoming a tool for settlement and clearing, assisting in the implementation of investments that are more efficient, helping those who need to save, borrow funds and participate in capital. ${ }^{18}$

The benefits arising from the presence of fintech is that consumers get better services, more choices and lower prices. As for product or service traders, the presence of fintech can provide a new color in helping traders' operations. For example, in simplifying transactions so as to reduce operational costs and capital costs and freeze the flow of information. For a country fintech also provides a very significant benefit that is encouraging the transmission of economic policy, increasing the velocity of money so that it improves the people's economy. In Indonesia fintech even helped push the national financial inclusive strategy (SKNI).

\section{Overview of Islamic law against the use of Go-Pay in paying zakat}

A contract with other people is born from the need to interact and interaction is a social necessity that has existed since the past and developed as the community grows. At present the contract cannot be separated from the social life of society given that humans are social creatures who need each other.

A contract is a form of agreement that occurs between two or more people through consent and qabul. So, if there is only one party who wishes it is not said to be a contract. The basic principle of the contract is the obligation to fulfill it

18 "Manfaat Fintech," accessed November 14, 2019, www.bi.go.id/id/edukasi-perlindungankonsumen/edukasi/produk-dan-jasa sp/fintech/pages/default.aspx. 
unless there is an argument that specifies it, and then the principle of the contract itself is the pleasure of both parties who entered into the contract and the outcome is mutually determined in the contract. Related to the pillars of the contract, the majority of scholars besides Hanafiyah said that the terms of the agreement consisted of three kinds, namely two people who had the intention ('aqidain), the object that was made a contract (ma'qud'alaih) as well as the expression of consent and qabul (shighah). ${ }^{19}$

The requirements of 'aqidain must be fulfilled namely he must have experts and regions. Ahliyah here means that both have the skills and compliance to conduct transactions. Usually these experts are obtained when they have reached the height and understanding. Whereas territory can be interpreted as a person's right or authority in conducting transactions. That is, the person is indeed the original owner, guardian or representative of an object brought in. So that he has the right and authority to conduct transactions. ${ }^{20}$

Referring to the harmonious theory and the terms of the contract above, it can be explained that in the first pillar, namely 'aqidain. Regarding the problem being analyzed, as for the aqid, PT Gojek as a facilitator provides zakat payment services with Go-Pay. In addition, there is the BAZNAS as a recipient of zakat through Go-Pay. The requirements as 'aqidain have also been met by seeing'experts and the area of the two institutions as institutions that are able to fit their capacity. While the object of the contract ( $m a^{\prime}$ qud 'alaih) is e-money which is used as a means of payment. The last pillars are consent and qabul. In practice consent and qabul have been implemented which are manifested in the form of actions or cues. Speech can be expressed in a variety of forms that most importantly can represent the desired goals and objectives. When users top up and / or make payments using Go-Pay, the user is indirectly satisfied with the transaction. Thus, based on previous exposure, it appears that the terms and conditions of the Go-Pay contract have been fulfilled.

The form of the agreement or statement between Go-Pay and PT Dompet Karya Anak Bangsa that the e-money balance stored in the Go-Pay application is not a savings account, so there is no interest charged. In this case there is no specific agreement between Go-Pay users and Go-Pay companies. It's just the terms and conditions that guide all users. ${ }^{21}$ The elements contained in the Go-Pay issued on the basis of the value of money that was first deposited to the holders of the Gojek. Then the e-money in the Go-Pay will be managed by issuers who are not as deposit funds such as banks. ${ }^{22}$ Whereas in Bank Indonesia Regulation it is also not regulated to the form of an agreement between the issuer and the user. Similar to the DSN-MUI fatwa number 116 / DSN-MUI / IX / 2017 concerning sharia

${ }^{19}$ Abdullah al-Mushlih dan Sah ash-Shawi, Ma La Yasa'ut Tajiru Jabluhu: Terjemah Oleh Abu Umar Basyir Fikih Ekonomi Keuangan Islam (Jakarta: Darul Haq, 2001), p. 27.

${ }^{20}$ Dimyauddin Djuwaini, Pengantar Figh Muamalah (Yogyakarta: Pustaka Pelajar, 2008), p. 57.

${ }^{21}$ Fauzul Razi, “Analisis Praktik Go-Pay Pada Aplikasi Gojek Untuk Transaksi Non-Tunai Dalam Perspektif Akad Qard” (Universitas Islam Negeri Ar-Raniry Darussalam, 2019), p. 20.

${ }^{22}$ Sukma Indra et al., “Transaksi E-Money Terhadap Layanan Go-Pay Pada Aplikasi Go-Jek Perspektif Ekonomi Syariah," n.d., 49-58, p. 49-58. 
electronic money, the fatwa regulates the agreement that can be used between the issuer (PT Dompet Anak Bangsa) and the organizer of electronic money (Go-Pay), namely ijarah contract, ju'alah contract and wakalah contract bil ujrah. Arranged also the contract between the organizer of e-money (Go-Pay) with e-money users, while the contract used is the wadiah contract and the qard contract. However, the forms of contracts stipulated in the fatwa are still ambiguous, meaning that they have not yet reached the level of clarity of the contract that must be used. Because the form of the contract depends on the user's intention when topping up. While the intention is not written nor spoken. So, it is not known whether the user considers the money deposited into a form of savings or loans. So that the contract attached to the transaction made is also dynamic so that it does not find the accuracy of the contract.

If the user considers the top up to be in the form of a wadiah (deposit) then e-money in Go-Pay cannot be used by the Gojek company. However, if the user receives benefits from the Gojek application then it is fine. In contrast to the qard (loan) agreement, if the user considers Go-Pay as a loan then it is fine if the Gojek company uses the user's e-money. But users may not get benefits from these loans in the form of discounts or the like, because they receive benefits from loans, including usury. ${ }^{23}$ If it is classified in more detail, in practice Go-Pay users do not know that their top-up funds have been used for whatever. The Gojek only collect funds from all application users for corporate investment purposes.

Zakat aside from being a pillar of faith which is a form of worship of the mahdhah to Allah SWT. Zakat also functions to improve the welfare of the Ummah and minimize poverty. Empirically that happens, that zakat is a solution to eradicate social inequalities under the management of BAZNAS and other zakat institutions. To explore the potential for greater levels of public awareness in paying zakat, BAZNAS issued a zakat collection policy which was considered very solutions by paying zakat through Go-Pay.

Paying zakat through Go-Pay is one of the ways taken by BAZNAS to collect zakat by seeing that people today tend to follow trend technology using fintech. So, with this strategy the collection of zakat can touch all levels of society even to the part of the RT or RW. Because payment through Go-Pay makes it easier for people without having to visit the BAZNAS office directly. ${ }^{24}$

In its implementation, PT Gojek facilitates these payments through QR codes or directly pays through the Go Bills feature with the aim of making it easier for muzakki especially the millennials to pay zakat. This means that Go-Pay is only a non-cash payment tool or media. By issuing zakat payment policies through GoPay, BAZNAS expects an increase in zakat receipts that have been targeted. From the implementation of zakat payment through Go-pay, it is clear that the parties involved are Go-Pay and BAZNAS.

${ }^{23}$ Agus Agung Susilo, “Transaksi Go-Pay Pada Perusahaan Ojek Online Perbandingan Akad Qard Dan Wadiah" (Universitas Islam Negeri Maulana Malik Ibrahim, 2018), p. 71.

${ }^{24}$ Fathimatuz Zahroh, "Analisis Efisiensi Pada Implementasi Fintech Dalam E-Zakat Sebagai Startegi Penghimpunan Dana Zakat Oleh LAZISMU Dan Nurul Hayat" (Universitas Islam Negeri Sunan Ampel Surabaya, 2019), p. 129. 
Referring to the contract theory that has been explained previously, in terms of the provisions of 'aqidain that BAZNAS as a place for collecting zakat in the form of legal entities has experts in carrying out their duties and responsibilities. Because for legal subjects in the form of a legal entity the skills of a body are seen from the management of the legal entity itself. So that baligh qualification, understanding and even competence in the field of work seen from the board. In addition, BAZNAS also has full rights and authority in collecting zakat even at the national level based on the decision of the President of the Republic of Indonesia No. 8 of 2001.

Furthermore, for a motorcycle which is positioned as a facilitator in providing the zakat payment media, of course, the motorcycle also has legal skills as an 'aqidain. In addition to competence goek administrators as legal subjects representing their legal entity (Gojek). The legal process is seen from the ability of the gojek providing zakat payment services in the form of Go-pay. Apart from the ability of id 'aqidain, then about ma'qud 'alaih in this discussion, namely electronic money in Go-Pay which is the object of zakat payment.

Something very important to be outlined in this discussion is the law of using Go-Pay. Before analyzing the law of using electronic money such as Go-Pay, it is first necessary to consider several provisions in the DSN-MUI fatwa no. 116 / DSN-MUI / IX / 2017 concerning electronic money. Islamic electronic money is electronic money in accordance with Islamic principles. This means that there are provisions and restrictions on the operation and use that must be met. Electronic money must be avoided from transactions containing ribawi, gharar, maisir, tadlis, risywah, israf and transactions on illicit or immoral objects. ${ }^{25}$

In the DSN-MUI fatwa number: 116 / DSN-MUI / IX / 2017 concerning Electronic Money, it is stated that electronic money may be used as a means of payment by following the provisions contained in this fatwa. The provisions are as follows:

1. Specific provisions that the nominal amount of electronic money available at the issuer must be placed in an Islamic bank. In addition, if the card used as electronic money is lost, the nominal amount of money in the issuer must not be lost.

2. Provisions relating to legal contract and personnel: The contract between the issuer and the holder of the electronic money is a wadi'ah contract or a qardh contract. In the event that the contract used is a wadi'ah contract, the following terms and conditions apply for the wadi'ah contract:

a) The nominal amount of electronic money is entrusted by the holder at any time;

b) The nominal amount of electronic money deposited may not be used by the depositor (the issuer), except with the permission of the card holder;

25 “Fatwa Dewan Syariah Nasional Majelis Ulama Indonesia Nomor 116/DSN-MUI/IX/2017 Tentang Uang Elektronik Syariah." (n.d.). 
c) In the event that the nominal amount of electronic money deposited is used by the issuer with the permission of the card holder, the deposit agreement (wadi'ah) changes to a loan agreement (qardh), and the responsibility of the depositor is the same as the responsibility in the qardh contract;

d) The relevant authorities are obliged to limit issuers in the use of deposit funds from card holders (float funds);

e) The use of funds by the issuer must not be in conflict with Islamic principles and statutory regulations.

Regarding the halal status of Go-Pay, contemporary scholars seem to differ in their views. Ahmad Sarwat believes that if you pay attention to Go-Pay, when someone does a top up then the money is not borrowed but is deposited so that the contract is wadi'ah. Therefore, the Gojek company is not borrowing money from users, so if benefits arise such as discounts, promos or cash back then those benefits are lawful benefits.

There is also an opinion from Erwandi Tarmizi who views that the Go-Pay system is depositing money first. Deposit means that the money is deposited so that it cannot be used even if it is replaced, but if the contract is a loan, then the money can be used. So today, if there are various promos until the discount for Go-Pay users is a form of marketing strategy to attract other people to deposit their money on Go-Pay. If the user utilizes the discount then there is usury there so it is unlawful. ${ }^{26} \mathrm{He}$ more firmly said that the more users through deposits, the company will be more profitable because the turnover of company money is faster. So, promos and discounts are used as an attraction to attract the interest of users. ${ }^{27}$

Meanwhile, according to Oni Sahiron's view as a solution so that the GoPay feature is in accordance with sharia, the Go-Pay money must be placed in an Islamic bank. Furthermore, Go-Pay which is deposited money if used by the Gojek company, the contract is changed into a debt and credit agreement. Then for the user, of course, they must know whether the digital money has received a halal certificate from an institution that has a fatwa authority. ${ }^{28}$ In contrast to the opinion of other contemporary scholars according to Zaim Saidi, Go-Pay as electronic money which is now a financial system is unlawful because the transactions are unseen or unclear. Because Go-Pay as entrusted funds are used by companies without asking permission from the fund owner in advance. ${ }^{29}$

The differences of opinion of the contemporary scholars above depend very much on the intention of Go-Pay users to top up Go-Pay so that the resulting

\footnotetext{
26"Pendapat Erwandi Tarmizi Tentang Go-Pay," accessed February 22, 2020, https://www. youtube.com/watch?v=2AM3yYQ3uYY.

${ }^{27}$ Wienda Fitri Rahayu, "Perspektif Syariah Tentang Metode Pembayaran Jual Beli Barang Atau Jasa Di Gojek Menurut Pendapat Ulama Di Media Sosial" (Universitas Islam Negeri Syarif Hidayatullah, 2019), p. 20.

${ }^{28 " P a n d a n g a n}$ Oni Sahiron Tentang Go-Pay," accessed February 22, 2020, https://www.youtube.com/watch?v=75cMMypuiqE, diakses pada tanggal .

29"Pendapat Zaim Zaidi," accessed February 22, 2020, https://www.youtube.com/watch?v=1KZYxnWA_f8,
} 
law is very complex because it is different in seeing the fiqh adaptation. If the user considers Go-Pay to be entrusted, then when it is used by Go-Pay, the law is haram. However, when the funds are intended as accounts payable, then the law may be used by the company.

Opinions that forbid Go-Pay even state that Top Up in Go-Pay is in the form of accounts receivable debt in which the customer provides debt through Top Up to Gojek. So, if there is a discount on the Gojek application service through GoPay, the benefits incurred are haram. So that Go-Pay becomes haram also if there is a difference in the price of the product or service between payments through GoPay with cash payments. However, those who allow Go-Pay also have different opinions in interpreting Gojek discounts or promos. ${ }^{30}$ According to those who allow, promos that are born from payment transactions through Go-Pay are an urgent ijarah agreement. This is based on the provisions of Go-Pay which is a virtual wallet to pay for all transactions in the Gojek and Go-Pay application cannot be cashed or returned. This means that the Gojek does not wish to accept the cancellation of a transaction contract, for those who have purchased a Go-Pay voucher. This condition is different from the debt and credit agreement. In a loan agreement, the money we give to the recipient of the debt must be returned, and as long as the money is still there, it will not be forfeited until it is repaid. ${ }^{31}$

During the top-up process, there was no form of option from the motorcycle taxi application as a representation of the company in binding a contract agreement between the user and the publisher. Both top-ups via banks, Indomaret groups or through drivers. So that it refers to the practice of using GoPay that the contract used in the Go-Pay is in the form of a wadi'ah contract, which is the Go-Pay fund belonging to the gojek user only as deposit fund. In terms of the characteristics of Go-Pay, one of them is that Go-Pay users can use or withdraw it at any time, whereas if the contract is receivable, certainly the debt receivable is identical to the term or maturity. ${ }^{32}$ This time period is not found in Go-Pay transactions. So as a consequence of the wadiah contract is the wadiah fund or GoPay may not be used by the gojek company without pocketing permission from the owner of the Go-Pay fund. This provision is explained in the DSN-MUI fatwa no. 116 / DSN-MUI / IX / 2017 concerning Electronic Money letter b paragraph 2.

Noting the above fatwa provisions then also seen in Bank Indonesia Regulation No 20/6 / PBI / 2018 concerning Electronic Money article 48 paragraph 2 which reads:

Article 48

\footnotetext{
${ }^{30}$ Muhammad Yunus, Fahmi Fatwa Rosyadi Satria Hamdani, and Gusti Khairina Shofia, “TINJAUAN FIKIH MUAMALAH TERHADAP AKAD JUAL BELI DALAM TRANSAKSI ONLINE PADA APLIKASI GO-FOOD," Amwaluna: Jurnal Ekonomi Dan Keuangan Syariah 2, no. 1 (January 31, 2018): 135-46, doi:10.29313/amwaluna.v2i1.3363, p. 13.

${ }^{31}$ Sylvia Gunasera Hafizah S, “Tinjauan Hukum Islam Terhadap Layanan Transaksi Digital Pada Financial Technology (Studi Layanan Gopay PT. Gojek Indonesia)” (Universitas Lampung fakultas Hukum, 2018), p. 2.

${ }^{32}$ Agus Agung Susilo, "Transaksi Go-Pay Pada Perusahaan Ojek Online Perbandingan Akad Qard Dan Wadiah", p. 71.
} 
(2) Issuers are required to place float ${ }^{33}$ funds with the following conditions:

a. At least $30 \%$ (thirty percent) of float funds in:

1) Cash, for issuers which are banks included in the category of commercial banks based on business activities (BOOK) 4; or

2) Current accounts at banks which are included in the category of commercial banks based on business activities (BOOK) 4, for:

a) Issuers that are banks not included in the category of commercial banks based on (BOOK) 4; and

b) Issuers which are institutions other than banks.

b. At most $70 \%$ (seventy percent) of float funds in:

1) Securities or financial instruments issued by the government or Indonesian banks; or

2) Account at an Indonesian bank.

Based on the regulations above, it turns out that $30 \%$ of Go-Pay float funds are in current accounts at commercial banks with core capital (minimum capital requirement) based on BOOK $4^{34}$, specifically for publishers of non-bank financial institutions. Based on data from the financial services authority, up to now commercial banks are included in the four BOOK categories, namely Bank Mandiri, Bank BRI, Bank BCA, BNI, CIMB NIAGA, and Panin bank. ${ }^{35}$ From this data it is clear that there is no Islamic bank in the category of BOOK four so that Go-Pay electronic money is still stored in conventional commercial banks.

Looking at the implementation of zakat payments through Go-Pay, the type of contract used by PT Gojek with BAZNAS is a wakalah bil ujrah agreement. The case in the Financial Services Authority Regulation Number 31 / POJK.05 / 2014 concerning Sharia Business Financing is defined as granting power of attorney from power provider (muwakkil) to the power of attorney (representative) in matters that may be represented, where the power of attorney (representative) does not bear the risk of what is represented, except because of carelessness or

${ }^{33}$ Float funds are the entire value of electronic money at the issuer for the results of the issuance of electronic money and / or refill (Top Up) which is still the obligation of the issuer to users and providers of goods and / or services. See, "Peraturan Bank Indonesia No 20/6/PBI/2018 Tentang Uang Elektronik Bab 1 Pasal 1." (n.d.).

${ }^{34}$ BOOK 1 (commercial banks based on business activities) are grouped into four BOOKS, namely: 1) BOOK 1 is a bank with a core capital of less than IDR 1,000,000,000,000 (one trillion). 2) BOOK 2 is a bank with a core capital of at least IDR 1,000,000,000,000 (one trillion) up to less than IDR 5,000,000,000,000 (five trillion). 3) BOOK 3 is a bank with a core capital of at least IDR $5,000,000,000,000.00$ (five trillion) to less than IDR 30,000,000,000,000 (thirty trillion); and 4) BOOK 4 is a bank with a core capital of at least IDR 30,000,000,000,000 (thirty trillion). "Peraturan Otoritas Jasa Keuangan Nomor 6/POJK.03/2016 Tentang Kegiatan Usaha Dan Jaringan Berdasarkan Modal Inti Bank" (n.d.).

35 “Otoritas Jasa Keuangan, Laporan Statistik Perbankan Indonesia," Vol 17 Nomor 02, n.d., www.ojk.go.id. 
default while wakalah bil ujrah is defined as wakalah with the imposition of compensation for services (ujrah). ${ }^{36}$

In order to make the contract analysis more comprehensive before describing the contract analysis, it will first be seen in harmony along with the ujrah in the payment of zakat through Go-Pay, that is, the person who represents or muwakkil (muzakki), the person who receives a representative or representative (Go-Pay), the object that receives a representative or representative muwakkil bihi (BAZNAS). Furthermore, the object that was formed in this collaboration is the value of electronic money or muzzaki's Go-Pay that will be paid zakat. Something very important to know is the clarity of the qabul consent in the payment of zakat online, the shighah agreement which is the consent and qabul of zakat payment between muzakki and BAZNAS continues to be implemented. The consent is done through the joy of muzakki who pays zakat, when muzakki pays zakat it means there is already a willingness and pleasure in the payment of zakat and then qabul also occurs through notifications that appear after the transaction. The reason is after zakat is paid. Muzakki will receive a notification, there will be a pop-up display in the form of a thank you for the zakat that has been paid. ${ }^{37}$ Shighah contract in this case is manifested in the form of the actions of the parties.

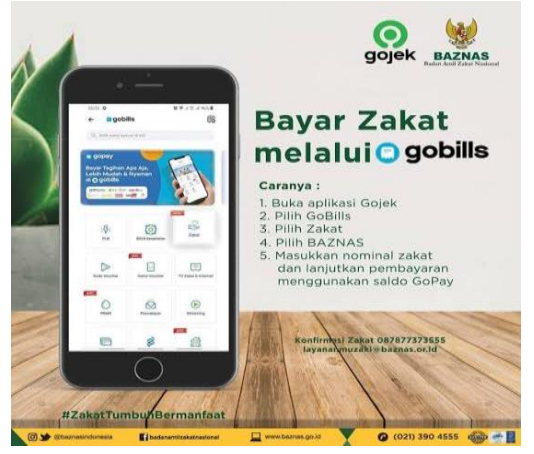

Picture 1

Steps for paying zakat through Go-Pay

Contract wakalah bil ujrah is seen from muzakki who pays his zakat through the Gojek application. Where there is a muzakki representative namely Go-Pay then forward the zakat to BAZNAS. This means that there is a Go-Pay in the midst of paying zakat between muzakki and BAZNAS.

Go-Pay as a profit company will certainly always take advantage of the collaboration it does. As a representative, of course there is a ujrah that will be obtained by Go-Pay in its position as a facilitator, but the contribution takes the form of the use of zakat funds. The point is that when muzakki pays zakat through Go-Pay the zakat fund is transferred to Go-Pays before it is deposited to BAZNAS

${ }^{36}$ Destri Budi Nugraheni, "Analisis Fatwa DSN-MUI Tentang Wakalah, Hawalah Dan Kafalah Dalam Kegiatan Jasa Perusahaan Pembiayaan Syariah," Jurnal Media Hukum 2 (2017): 127, p. 127.

${ }^{37}$ Nurul Ula Ulya, "Legal Protection of Donation-Based Crowdfunding Zakat on Financial Technology (Digitalization of Zakat under Perspective of Positive Law and Islamic Law)," International Conference of Zakat 2018, 2018, 215-26, p. 218. 
as amil zakat body automatically. so that Go-Pay remains to benefit. In addition, Go-Pay also still gets the benefits not directly in the payment of zakat but is obtained from top up activities by users. So, the more electronic money users do top up (refill) then PT Gojek will benefit from the refill.

Based on the regulations No. 20/6/PBI/2018 about concerning electronic money article paragraph 2, it turns out that $30 \%$ of Go-Pay float funds are in current accounts, specifically issuers of non-bank financial institutions. Data from Bank Indonesia shows that the amount of electronic money in February 2019 was recorded at around 4 trillion $^{38}$ rupiah of 39 issuers of electronic money, ${ }^{39}$ if electronic money is deposited in current accounts assuming an interest of $2 \%$ per year then there is a potential profit of around 10 billion rupiah will be received.

Then $70 \%$ of the funds are in government securities (SBN) or financial instruments issued by the government or Bank Indonesia. This means that the placement of these funds is deposited in investment instruments with substantial results that can be obtained by the issuer of electronic money through state securities or bonds traded in the secondary market. So, the more Go-Pay users pay zakat, of course, the more users also top up, so that float funds will continue to grow and the company will reap huge profits.

From the whole description above, the writer found a bright spot from the zakat payment agreement through go-pay, which is not allowed. The cause:

First, this failure is caused by the provisions contained in the fatwa of DSNMUI Number: 116 / DSN-MUI / IX / 2017 concerning Electronic Money. Whereas in the fatwa it was explained that electronic money could be used if the float funds were placed in a temporary Islamic bank in the provisions of the Bank Indonesia regulation. Float funds were placed $30 \%$ in the gyro category of commercial banks while there were no Islamic banks in the category of BUKU 4.

Second, $70 \%$ of float funds are placed in state securities (SBN) or financial instruments issued by the government or Bank Indonesia. Thus, the float funds will be invested or traded in the secondary market. Whereas in the provisions of the fatwa DSN-MUI Number: 116 / DSN-MUI / IX / 2017 the agreement between the user of electronic money and the issuer of electronic money (Go-Pay) is a wadi'ah contract or deposit so that the issuer may not use it without the permission of the owner.

\section{Conclusion}

Based on the previous explanation, the authors conclude that Go-Pay electronic money should not be used because it is not in accordance with the provisions of DSN-MUI because electronic money must be placed in an Islamic bank. Because, when Go-Pay is stored in a conventional bank, of course, this will contain elements of usury which violate the provisions and limitations of the administration and use of electronic money. Furthermore, when electronic money

38 “Laporan Bank Indonesia," n.d., file://C:/Users/Acer/Downloads/Jumlah Uang Elektronik Beredar.pdf www.bi.go.id.

39 “Penyelenggara E-Money," n.d., www.bi.go.id/id/statistik/sistem-pembayaran/uang elektronik/Contents/Penyelenggara Uang Elektronik.aspx. 
or Go-Pay cannot be used based on the DSN-MUI fatwa, Go-Pay also cannot be used to pay zakat through Go-Pay.

\section{References}

Abdullah al-Mushlih dan Sah ash-Shawi. Ma La Yasa'ut Tajiru Jabluhu: Terjemah Oleh Abu Umar Basyir Fikih Ekonomi Keuangan Islam. Jakarta: Darul Haq, 2001.

Agus Agung Susilo. “Transaksi Go-Pay Pada Perusahaan Ojek Online Perbandingan Akad Qard Dan Wadiah." Universitas Islam Negeri Maulana Malik Ibrahim, 2018.

Bank for Internatinal Settlement. Implications for Central Bank of the Development of Electronic Money. BIS, 1996.

Chang, William. Metode Penulisan Esai, Skripsi, Tesis, Dan Disertasi Untuk Mahasiswa. Jakarta: Erlangga, 2014.

Committee on Payment and Settlement Systems. "Survey of Developments in Electronic Money and Internet and Mobile Payment," 2004.

Departemen Pendidikan Nasional. Kamus Besar Bahasa Indonesia. Jakarta: Balai Pustaka, 2007.

Destri Budi Nugraheni. "Analisis Fatwa DSN-MUI Tentang Wakalah, Hawalah Dan Kafalah Dalam Kegiatan Jasa Perusahaan Pembiayaan Syariah." Jurnal Media Hukum 2 (2017): 127.

Dimyauddin Djuwaini. Pengantar Figh Muamalah. Yogyakarta: Pustaka Pelajar, 2008.

Fatwa Dewan Syariah Nasional Majelis Ulama Indonesia Nomor 116/DSNMUI/IX/2017 Tentang Uang Elektronik Syariah. (n.d.).

Fauzul Razi. "Analisis Praktik Go-Pay Pada Aplikasi Gojek Untuk Transaksi NonTunai Dalam Perspektif Akad Qard." Universitas Islam Negeri Ar-Raniry Darussalam, 2019.

Indonesia, Bank. PERATURAN BANK INDONESIA NOMOR: 11/12/PBI/2009 TENTANG UANG ELEKTRONIK (ELECTRONIC MONEY) DENGAN, 2 $\S(2009)$. ???

Indra, Sukma, Zuliana Rofikoh, Sukma Indra, Zuliana Rofiqoh, and Ekonomi Syariah. "Transaksi E-Money Terhadap Layanan Go-Pay Pada Aplikasi Go-Jek Perspektif Ekonomi Syariah," n.d., 49-58.

"Laporan Bank Indonesia," n.d. file:///C:/Users/Acer/Downloads/Jumlah Uang Elektronik Beredar.pdf www.bi.go.id.

Lexy Moleong J. Metodologi Penelitian Kualitatif. Bandung: PT Remaja Rosdakarya, 2016.

M Cholil Nafis. Teori Hukum Ekonomi Syariah. Jakarta: Universitas Indonesia Press, 2011.

"Manfaat Fintech." Accessed November 14, 2019. www.bi.go.id/id/edukasiperlindungan-konsumen/edukasi/produk-dan-jasa $\mathrm{sp} /$ fintech/pages/default.aspx.

Miftahul Huda. Pengelolaan Wakaf Dalam Perspektif Fundraising. Jakarta: Kementrian Agama RI, 2012. 
Nengsih, Novia. "ANALISIS TERHADAP FATWA DEWAN SYARI'AH NASIONAL MAJELIS ULAMA INDONESIA (DSNMUI) TENTANG UANG ELEKTRONIK SYARIAH (Studi Kartu Flazz BCA, Go-Pay, Dan Grab-Pay)." Jurisdictie 10, no. 1 (2019): 56. doi:10.18860/j.v10i1.6594.

"No Title." Accessed November 4, 2019. www.gojek.com/gopay/kebijakanprivasi/.

“Otoritas Jasa Keuangan, Laporan Statistik Perbankan Indonesia." Vol 17 Nomor 02, n.d. www.ojk.go.id.

P.D, Sugiono. Metode Penelitian Pendidikan Pendekatan Kuantitatif.Pdf. Metode Penelitian Pendidikan Pendekatan Kuantitatif, Kualitatif Dan RED, 2014.

"Pandangan Oni Sahiron Tentang Go-Pay." Accessed February 22, 2020. https://www.youtube.com/watch?v=75cMMypuiqE, diakses pada tanggal

“Pendapat Erwandi Tarmizi Tentang Go-Pay." Accessed February 22, 2020. https://www.youtube.com/watch?v=2AM3yYQ3uYY.

“Pendapat Zaim Zaidi." Accessed February 22, 2020. https://www.youtube.com/watch?v=1KZYxnWA_f8,.

"Penyelenggara E-Money," n.d. Www.bi.go.id/id/statistik/sistempembayaran/uang elektronik/Contents/Penyelenggara Uang Elektronik.aspx.

Peraturan Bank Indonesia No 20/6/PBI/2018 Tentang Uang Elektronik Bab 1 pasal 1. (n.d.).

Peraturan Otoritas Jasa Keuangan Nomor 6/POJK.03/2016 Tentang Kegiatan Usaha dan Jaringan Berdasarkan Modal Inti Bank (n.d.).

Surat Keputusan Menteri Keuangan Republik Indonesia Nomor 792 Tahun 1990 Tentang Lembaga Keuangan. (n.d.).

Sylvia Gunasera Hafizah S. “Tinjauan Hukum Islam Terhadap Layanan Transaksi Digital Pada Financial Technology (Studi Layanan Gopay PT. Gojek Indonesia)." Universitas Lampung fakultas Hukum, 2018.

Tamrin Abdullah dan Francis Tantri. Bank Dan Lembaga Keuangan. 1st ed. Jakarta: Rajawali Press, 2012.

Tarazi, Kate Lauer dan Michael. "Supervising Nonbank E-Money Issuers'," 2010. www.cgaap. org/.../CGAP-Brief-Supervising-Nonbank-Emoney-\%3E.

Totok Budisantoso dan Nuritumo. Bank Dan Lembaga Keuangan Lain. Jakarta: Salemba Empat, 2017.

Ulya, Nurul Ula. “Legal Protection of Donation-Based Crowdfunding Zakat on Financial Technology (Digitalization of Zakat under Perspective of Positive Law and Islamic Law)." International Conference of Zakat 2018, 2018, 215-26.

Undang-Undang Nomor 14 Tahun 1967 Tentang Pokok-Pokok Perbankan (n.d.).

Wienda Fitri Rahayu. "Perspektif Syariah Tentang Metode Pembayaran Jual Beli Barang Atau Jasa Di Gojek Menurut Pendapat Ulama Di Media Sosial." Universitas Islam Negeri Syarif Hidayatullah, 2019.

Yunus, Muhammad, Fahmi Fatwa Rosyadi Satria Hamdani, and Gusti Khairina Shofia. “TINJAUAN FIKIH MUAMALAH TERHADAP AKAD JUAL BELI DALAM TRANSAKSI ONLINE PADA APLIKASI GO-FOOD." Amwaluna: 
Jurnal Ekonomi Dan Keuangan Syariah 2, no. 1 (January 31, 2018): 135-46. doi:10.29313/amwaluna.v2i1.3363.

Zahroh, Fathimatuz. "Analisis Efisiensi Pada Implementasi Fintech Dalam EZakat Sebagai Startegi Penghimpunan Dana Zakat Oleh LAZISMU Dan Nurul Hayat." Universitas Islam Negeri Sunan Ampel Surabaya, 2019. 